\title{
平板型電波吸収体を用いた小型電波暗箱内の 電磁界分布評価に関する検討
}

\author{
非会員 橋本 利紀* 非会員 安藤 孝明* \\ 非会員 大平 孝** 正 員 橋本 修*
}

A Study on Electromagnetic Distribution Evaluation using Monotonous Type Wave Absorber in Compact Anechonic Box

Toshinori Hashimoto*, Non-member, Takaaki Ando*, Non-member, Takashi Ohira**, Non-member, Osamu Hashimoto*, Member

\begin{abstract}
Variation of the electromagnetic (EM) field distribution in the anechoic box is calculated by finite difference time domain (FDTD) method. It is confirmed that quantitative relation between the performance of the wave absorber and the variation of EM field distribution under the condition that two types of the absorbers are installed with the wall of the box. Moreover, the effectiveness of the measurement of the anechoic box by using FDTD method is confirmed because the tendency of the analytical result of the magnetic field distribution is similar to its experimental result.
\end{abstract}

キーワード：電波暗箱，変動量分布，FDTD 法，電波吸収体

Keywords: anechoic box, variation of the electric field distribution, FDTD method, wave absorber

\section{1. まえがき}

近年，携帯電話や携帯情報端末などの無線通信機器の高 性能化が急速に進んでおり，产れらに用いられるアンテナ 特性の改善等のための測定が重要となってきている。これ らの測定は，一般にオープンサイトや電波暗室で行われる が , これらの測定場には広い場所を確保する必要があるこ とや，電波暗室は高価で維持も困難といった欠点がある。 そこで，電波暗室に比べて安価で，スペースを必要としな (小型な電波暗室 (以下，電波暗箱と称す。) ${ }^{(1) \sim(4)}$ の開発 が進められており，簡易なアンテナ特性等の測定や，アン テナ設計の効率化に用いられている。

従来，電波暗箱を設計する際には，レイトレーシング 法 $^{(5) \sim(7)}$ が用いられ，この方法で近似的に電波暗箱内部に おける電界分布が計算されている。しかし，この方法では 電波暗箱内の電磁界分布を直接観察することができず，内

\footnotetext{
$*$ 青山学院大学

于 229-8558 相模原市淵野辺 5-10-1

Aoyama Gakuin University

5-10-1, Fuchinobe, Sagamihara 229-8558

** ATR 適応コミュニケーション研究所

テ 619-0288 京都府けいはんな学研都市光台 2-2-2

Adaptive Communications Research Laboratories

2-2-2, Hikaridai, Keihanna Gakken City, Kyoto 619-0288
}

部の定在波分布を確認することができないため，良好な測 定を行うために暗箱内においてどのように被測定物や測定 用アンテナを配置するかといった定量的な検討ができない 問題があった。乥して, 暗箱内における近傍電磁界の測定 に誤差が生じると光の測定值を用いて near-far 変換して求 めたアンテナ指向性には大きな誤差が生じる問題があった。

弚こで，本論文では，電磁界を視覚的，時間的に観察で きる FDTD 法 ${ }^{(8)}$ を用い，電波暗箱内部の電磁界分布を計 算した。この方法によれば，壁面からの多重反射や回折波 等も計算できるため, 暗箱内部におけるより正確な電磁界 分布が得られる。光のため, 本論文では携帯電話のアンテ ナ特性の評価等を念頭におき, (1) 半波長ダイポールアン テナを配置し，また，(2) 暗箱壁面には内部空間を大きく するという実用的観点から 1 層型電波吸収体や，(3) 斜入 射特性をより良好にした，TE・TM 両偏波に整合させた 2 層型電波吸收体を装着した。光して, 電波暗箱内の電磁界 に対する評洒法については，乥れ光れの吸収体装着時にお ける内部の電界分布を自由空間の場合と比較し，後述する 変動量を用いて電波暗箱設計に対する資料を提供した。ま た，1 層型電波吸収体を用いた場合を例として磁界分布を 測定し，計算結果と比較することにより，電波暗箱の設計 に対する FDTD 法の有効性についても検討した。 


\section{2. 解 析}

〈2 1〉 吸収体について 本論文で想定している電波 吸収体は，電波暗箱に使用して，測定空間を広くできるも のを前提に考えており，平板型吸収体の裏側を金属で裏打 ちした構成である。なお，電波吸収体における「吸収量」 とは，完全反射体である金属板からの反射レベルに対して， 幾何学的に同面積の電波吸収体からの反射レベルがどの程 度低下するかによって定義される。

\section{$\langle 22\rangle$ 吸収体の設計}

$\langle 221\rangle \quad 1$ 層 型 1 層型電波吸収体として実際に製 品化されている磁性損失型 (TDK 製 IRB-024) の電波吸 収体に着目した。この吸収体の材料定数は $\dot{\varepsilon}_{r}=13-j 1.0$, $\dot{\mu}_{r}=1.8-j 1.0$ であり, $2 \mathrm{GHz}$ 帯において吸収量 $20 \mathrm{~dB}$ を越 える吸収体であることが分かっている。ここでは , $2.4 \mathrm{GHz}$ に整合するように製作したものを用いた。この吸収体の厚 みを実測した結果，平均 $5.95 \mathrm{~mm}( \pm 0.01 \mathrm{~mm})$ であり，この 実測値をもとに伝送線路理論により求めた吸収特性の計算 值は図 2および図 3に示す通りである。光して FDTD 法に よる解析においては, 吸収量について本手法による磁性損 失型電波吸収体の取り扱いに対する有効性を検討するため， 先に求めた伝送線路理論による計算値と比較検討をした。 FDTD 法による解析モデルおよび，解析諸元は図 1 ，表 1 のとおりである。光して吸収体にむけて平面波を励振させ， 入射波と反射波の樣子から吸収量を算出した。図3は光の 結果を示しており, FDTD 法と伝送線路理論による吸収量 の理論值とは傾向としてほぼ一致していることが確認され た。なお，多少の差異が生じているが，この理由は FDTD 法において吸収体を表現する際に境界付近のセルにおいて， 材料定数の平均値を用いているためにピークがずれたため と考えられる。

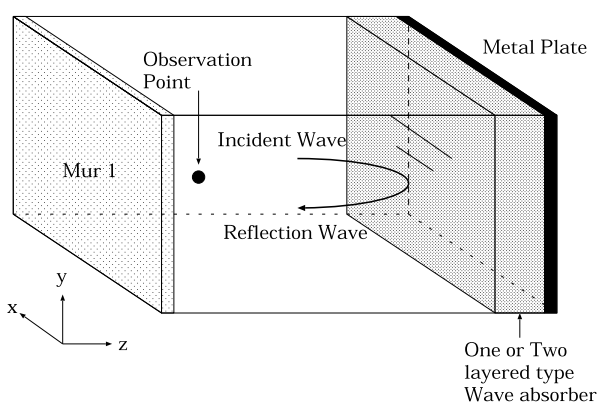

図 1 FDTD 法による解析モデル

Fig. 1. Analysis model for FDTD method.

表 1 各吸収体におけるセルサイズ

Table 1. Cell size for each wave absorber

\begin{tabular}{|c|c|c|}
\hline & One layered type & Two layered type \\
\hline Cell size & $\lambda / 84(1.488 \mathrm{~mm})$ & $\lambda / 50(2.5 \mathrm{~mm})$ \\
\hline Thickness & 4 cell $(5.95 \mathrm{~mm})$ & $30 \operatorname{cell}(75 \mathrm{~mm})$ \\
\hline
\end{tabular}

$\langle 222\rangle \quad 2$ 層 型 2 層型電波吸収体の性能として $\mathrm{TE} \cdot \mathrm{TM}$ 両偏波に整合したものに着目し，一例として 20 度と 40 度に整合するように吸収体を設計した。設計法 は, 文献 $(9)$ に示された 2 層型吸収体の設計チャートより $(d 1+d 2) / \lambda$ と $d 1 /(d 1+d 2)$ を光れ午れ $0.6,0.4$ と固定 し，整合角度 20 度と 40 度のときの複素比誘電率を二ュー トン法を用いて算出した。設計結果を表 2 に,この設計值 を用い，伝送線路理論による吸収体の吸収特性の計算値を 図 4 おび図 5 に示す。なお， 2 層型においても 1 層型と同 樣に, FDTD 法による 2 層型誘電損失型電波吸収体の取り 扱いに対する有効性を確認するため，20 度および 40 度に 整合した場合の周波数特性を計算した。解析モデルおよび 解析諸元は図 1 , 表 1 に示すとおりであり，光の結果を図 5 に示すが , これより 1 層型のときと同樣に理論值と計算結 果の吸収特性の傾向はほぼ一致していることが確認できた。 また，多少の差異の原因は先程と同樣であると考えられる。

〈2 3〉 解析モデル 電波暗箱の解析モデルは図 6 に示 すように, 解析空間の中心に携帯電話のアンテナ特性評価 等への利用を念頭に $2.4 \mathrm{GHz}$ の半波長ダイポールアンテナ

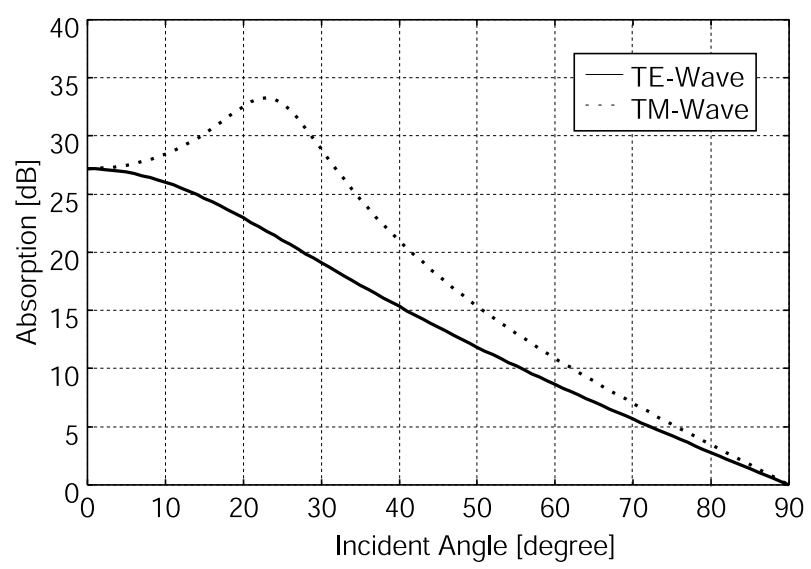

図 2 角度特性 (1 層型)

Fig. 2. Angle characteristics (one layered type).

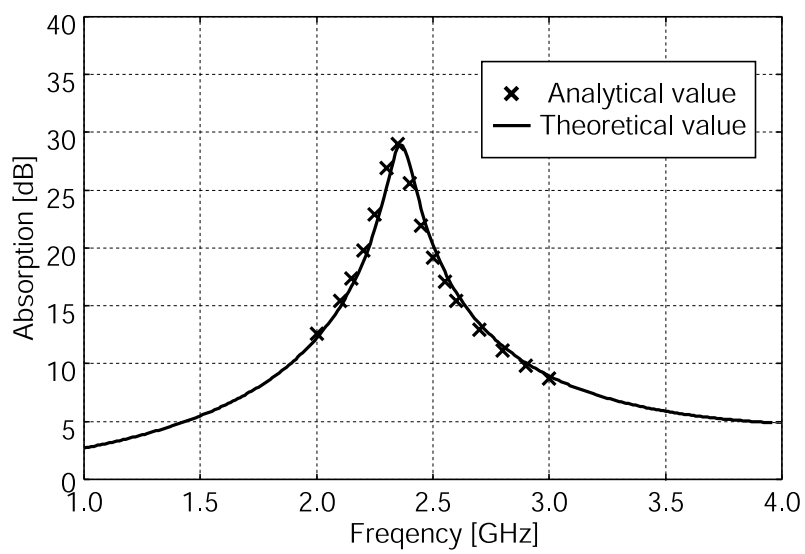

図 3 垂直入射に対する周波数特性 (1 層型)

Fig. 3. Freqency characteristic when incident angle is 0 degree (one layered type). 
表 2 設計諸元

Table 2. Designed values

\begin{tabular}{|c|c|c|c|}
\hline & 20 degree & 40 degree & Thickness \\
\hline First layer & $1.62-j 1.89$ & $1.85-j 1.78$ & $30 \mathrm{~mm}$ \\
\hline Second layer & $1.01-j 0.31$ & $1.14-j 0.24$ & $45 \mathrm{~mm}$ \\
\hline
\end{tabular}

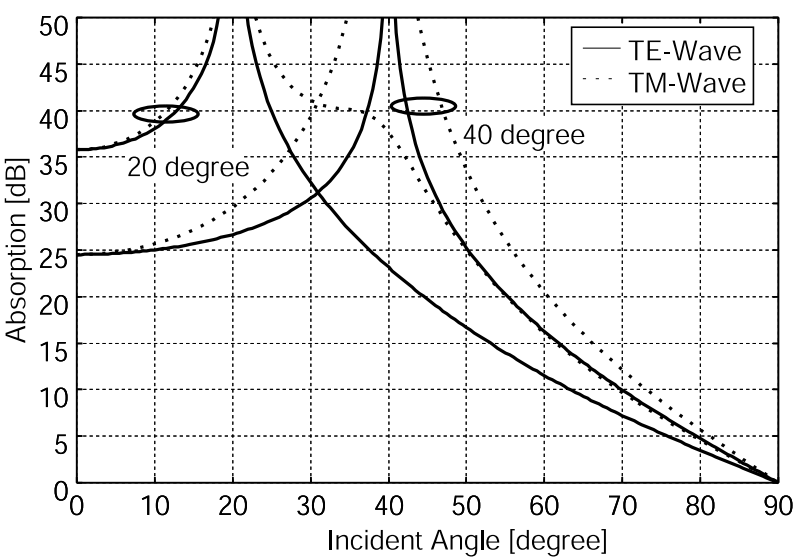

図 4 角度特性 (2 層型)

Fig. 4. Angle characteristics (two layered type).

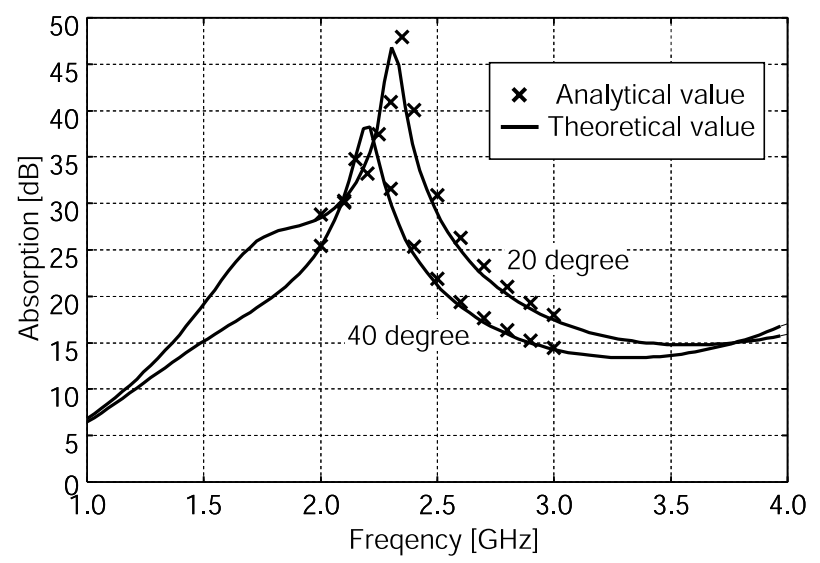

図 5 垂直入射に対する周波数特性 (2 層型)

Fig. 5. Freqency characteristic when incident angle is 0 degree (two layered type).

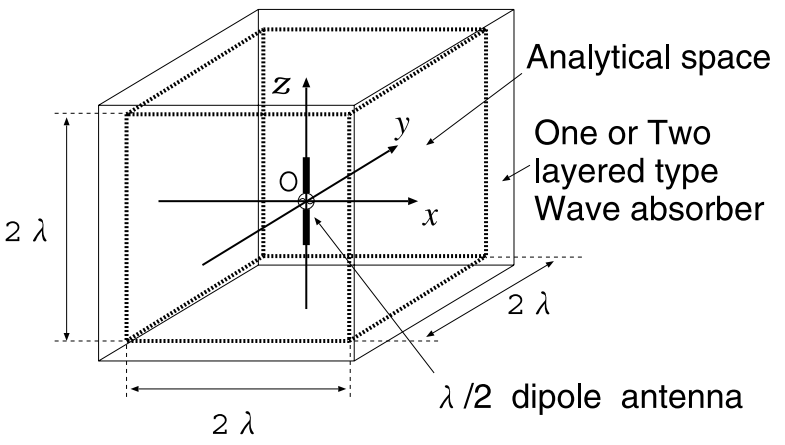

図 6 電波暗箱の解析モデル

Fig. 6. Analytical model of anechoic box. (z 方向)を配置したものである。光して，暗箱壁には，前

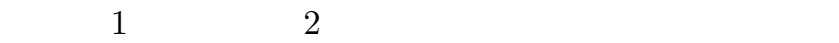
の場合における内部の電磁界分布を検討した。

解析におけるセルサイズは，先程の電波吸収体評価で用 いたものと同樣であり(表 1)，弚れ光れの吸収体の厚みを できるだけ多くのセルで表現し，また内部電磁界の樣子を

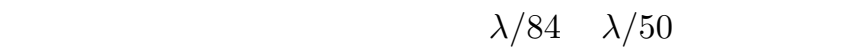
して，電波暗箱の四隅を構成するセルには，電波吸収体の 材料定数に，光の平均值をとることで表現した。ここで，暗 箱内部の大きさは，参考文献(10) にて検討を行っており， 本論文では実用的な大きさを考え $2 \lambda$ 立方空間とし，乥の時 の中央平面における電磁界を観察した。

〈2. 4 〉 評 価 法 電波暗箱内の電磁界分布の良好性を 示す指標として，PML 境界条件を用いて自由空間を想定 した場合の電界振幅値を基準 (吸収量 $100 \mathrm{~dB}$ の PML 境界 とした場合) とし, 変動量を以下の式で定義し算出した。

$$
\text { 变動量 }[\mathrm{dB}]=-20 \log \frac{\text { 評価する吸収体での電界振幅 }}{\text { 吸収量 } 100 \mathrm{~dB} \text { での電界振幅 }}
$$

この変動量が大きい箇所では，良好な電磁界の測定が困 難となることから，この測定值から near-far 変換して得ら れるアンテナの指向性に大きな誤差が含まれることが予想 される。また，変動量が小さい箇所は，自由空間における 測定と大差無く測定できることになる。

\section{3. 解析結果}

〈3 1 1 1 層 型 図 7に電波暗箱内部の中央面にお ける電界 Ez 成分の変動量分布を示す。計算結果において， 良好な測定領域を示すために, 変動量の下限と上限を一$1 \mathrm{~dB}$ に設定し分布を表現した。この図より壁面付近では変 動量が大きく, 中心付近では変動量が小さい領域があるな ど，変動量の分布が観察できた。このように領域によって 大きく変動量が変化するのは, 吸収体の吸収特性が入射角 度が大きくなるにつれて，劣化するため壁面で反射波が発 生し，場所によっては产の反射波が打ち消し合ったり強め あったりするためである。

〈3. 2〉2 層型图 8 , 図 $9 に 20$ 度, 40 度に整合し た吸収体を装着した場合の暗箱中央平面の電界 $\mathrm{Ez}$ 变動量 を示す。両図において先程同樣に良好な測定が行える領域 を示すために, 変動量の下限と上限を, $-1,1 \mathrm{~dB}$ として表 現した。この結果，図 $8 て ゙ は ， 20$ 度に整合させたことで暗 箱壁面部分における変動量が改善されていることや, 入射 角度 45 度付近まで $\mathrm{TE} \cdot \mathrm{TM}$ 両偏波ともに $20 \mathrm{~dB}$ を越える 吸収体であることから，中央平面全体において変動量が大 きく改善されていることがわかった。また，图 $9 て ゙ は 40$ 度 に整合させたことで暗箱の四隅部分での変動量が同じく改 善されていることが確認できた。

さらに, 先の図 2 と図 4より, 光れぞれの吸収体を装着し た場合の变動量として図 $7 と$ 図 9を比較すると壁面付近の 


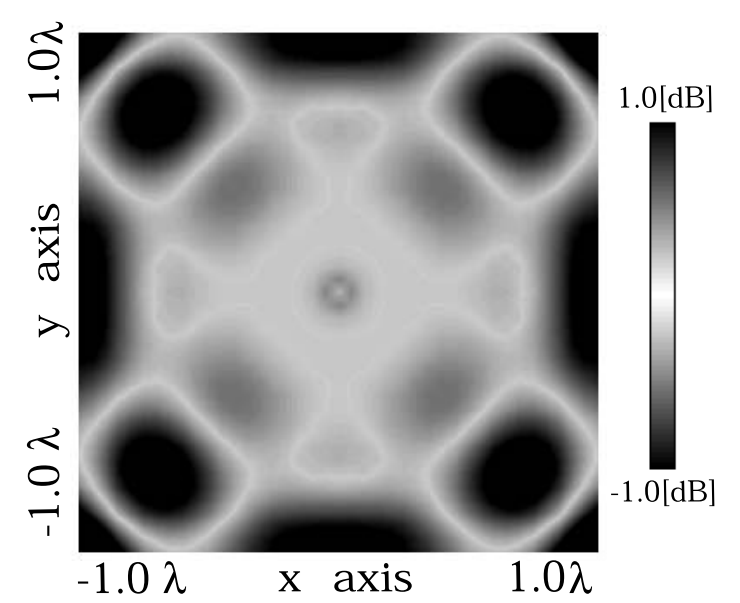

図 $7 \mathrm{Ez}$ 変動量 $(1$ 層型)

Fig. 7. Ez variation of the electric field distribution (one layered type).

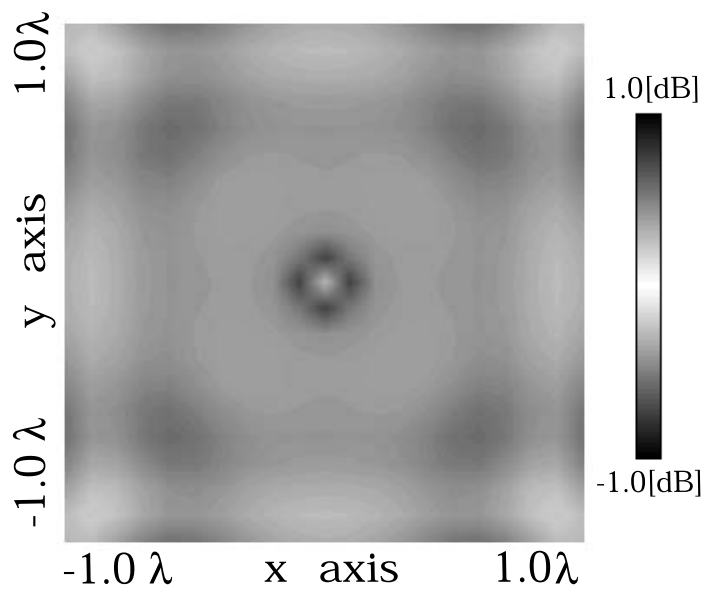

図 $8 \mathrm{Ez}$ 変動量 $(2$ 層型, 20 度 $)$

Fig. 8. Ez variation of the electric field distribution (two layered type, 20 degree).

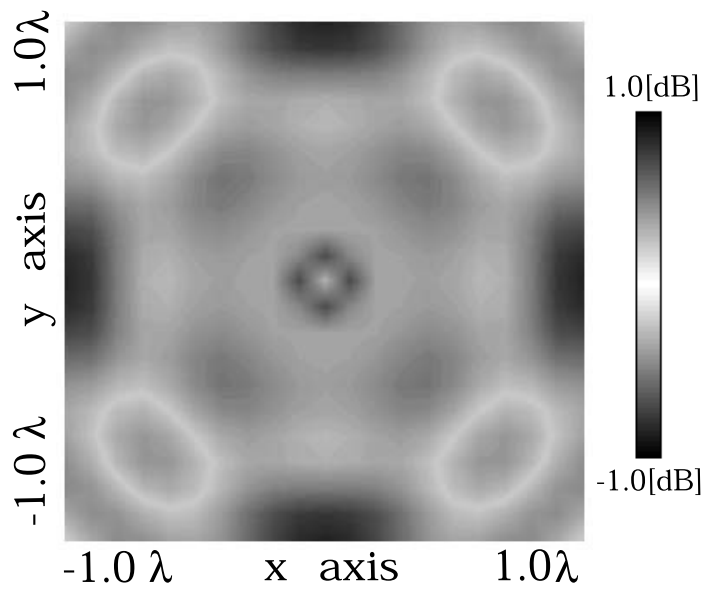

図 $9 \mathrm{Ez}$ 変動量 $(2$ 層型, 40 度 $)$

Fig. 9. Ez variation of the electric field distribution (two layered type, 40 degree).

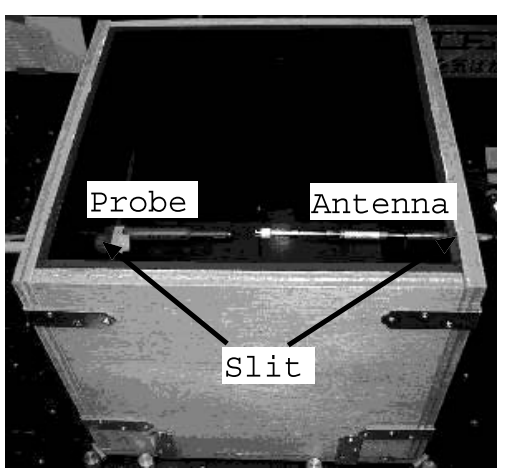

図 10 試作した電波暗箱の外観

Fig. 10. A trial producted anechonic box.

変動量は 2 層型吸収体の垂直入射特性が 1 層型吸収体と同 程度の吸収量であるにも関わらず，小さく抑えられている ことがわかった。この理由は，斜入射用の両偏波対応型吸 収体を装着したことで，電波暗箱内の多重反射を抑圧する ことができたためと考えられる。

\section{4. 実験方法}

以上の解析結果を比較するために，1 層型電波吸収体を用 いて電波暗箱を試作した。図 10に示すように試作した電波 暗箱は，解析モデルと同樣に内部空間を $2 \lambda$ 立方空間となる ように木材で箱を構成し，暗箱側面に半波長ダイポールア ンテナ (アンリツ株式会社 , MA5612B4 型) と磁界プロー ブを挿入できる程度に小さいスリットを設けた。この図に おいて , 向かって右側よりネットワークアナライザーから，

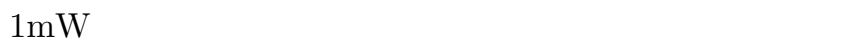
より磁界プローブの出力をスペクトラムアナライザーによ り測定した。なお，用いた磁界プローブは NEC 真空硝子 製 $(\mathrm{CP}-2 \mathrm{~S}$ 型)であり，以下に示すような構成係数を加える ことで磁界強度の算出が可能となる。

$$
\begin{aligned}
& H_{f}=V_{f}+A_{f} \\
& H_{f}: \text { 周波数 } f \text { での磁界強度 }[\mathrm{dB} \mu \mathrm{A} / \mathrm{m}] \\
& V_{f}: \text { 周波数 } f \text { での測定值 }[\mathrm{dB} \mu \mathrm{V}] \\
& A_{f}: \text { 周波数 } f \text { での構成係数 }[\mathrm{dB}] \\
& \text { ただし } A_{f}=-8.1 \ln (\text { 周波数 }[\mathrm{MHz}])+106.2
\end{aligned}
$$

そして, 観測面は解析と同樣に暗箱中央平面とし，磁界プ ローブの可動方向の関係上，磁界の $\mathrm{y}$ 方向成分 Hy $0.1 \lambda$ おきに約 250 箇所の測定を行った。ここで, 半波長ダイポー ルアンテナの支柱軸部において，反射が発生し，電磁界を みだすお弚れがあることが予想されたため，壁面に用いた 電波吸収体を支柱軸に巻かない場合と，巻いた場合の 2 方 法で測定を行った。

\section{5. 実験結果}

図 11に吸収体を巻かない場合を，図 12に吸収体を巻い た場合の測定結果を示す。両図おいて空白部分はアンテナ 


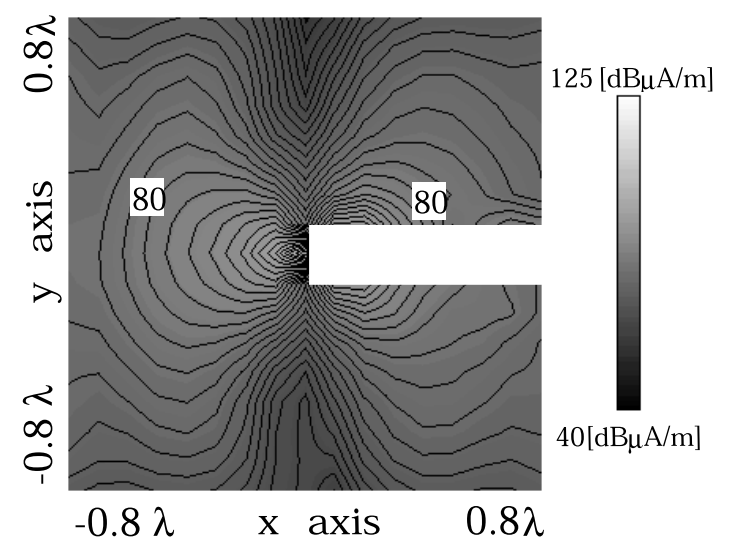

図 11 磁界 Hy の測定結果 (吸収体なし)

Fig. 11. Experimental result of Hy magnetic field (no absorber).

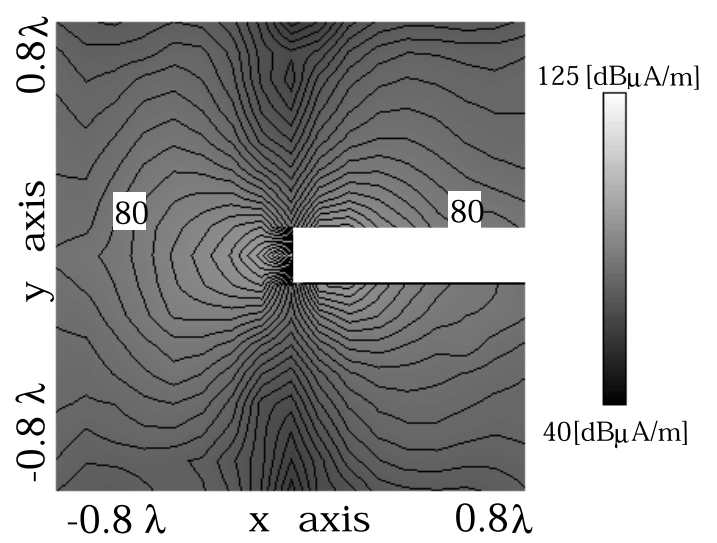

図 12 磁界 Hy の測定結果 (吸収体あり)

Fig. 12. Experimental result of Hy magnetic field (absorber).

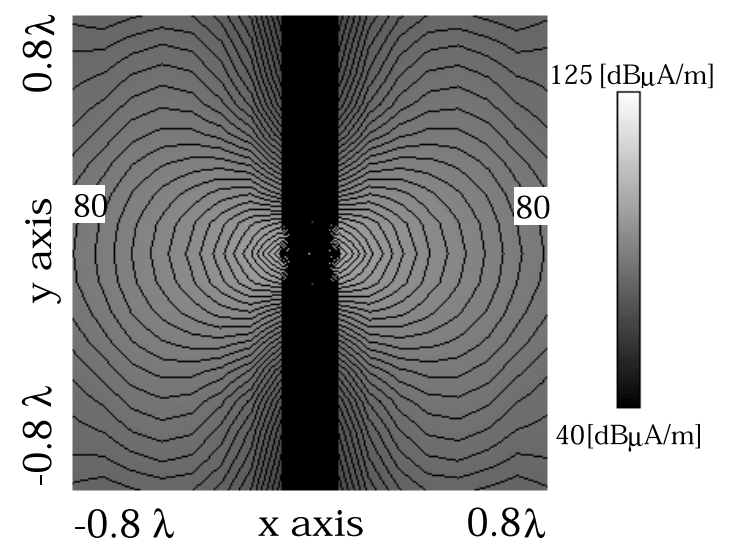

図 13 磁界 Hy の解析結果

Fig. 13. Analytical result of Hy magnetic field.

の支柱軸が存在する場所のため測定できなかった場所であ り，また，図中では磁界の変化傾向を分かりやすくするた
めに等磁線を設け，乥の間隔を $2[\mathrm{~dB} \mu \mathrm{A} / \mathrm{m}]$ として表現し た。この結果両図を比較すると，アンテナ支柱軸部分にお いて吸収体を巻かない場合，特に支柱軸の付近で大きな磁 界の乱れが観察できた。さらに，図 13に FDTD 法による 暗箱中央平面における磁界 Hy 成分を示す。この図におい ては，測定結果と比較できるように等磁線を設け，光の間 隔を測定と同樣に $2[\mathrm{~dB} \mu \mathrm{A} / \mathrm{m}]$ とした。この結果，図 12 と 図 13を比較すると，両図おいて磁界の強い箇所，弱、箇所， 乥して, 中央から $\mathrm{x}$ 軸方向へ磁界が緩やかに減衰し, $\mathrm{y}$ 軸 方向へは急激に減衰する樣子を含めて両図は良好に一致し ており，これより FDTD 法解析の有効性が示された。

\section{6. むすび}

以上本論文では, FDTD 法を用いて， $2 \lambda$ 立方電波暗箱内 の壁面に 1 層型， 2 層型電波吸収体を配置した場合の電界 分布を計算し，关の結果から自由空間を基準とした電界の 变動量分布を求めた。この結果，

（1） 1 層型吸収体では壁面からの反射の影響を大きく受 け，反射波と直接波が強めあったり打ち消しあうことから 変動量が大きく変化していることが定量的に観察できた。

（2） $\mathrm{TE} \cdot \mathrm{TM}$ 両偏波対応型の 2 層型吸収体では， 1 層 型吸収体に比べ変動量が大きく低減でき，また，垂直入射 特性があまり良好でなくても暗箱四隅付近の変動量を大き く改善できることがわかった。

（3） 1 層型電波吸収体を用いた場合を一例として実験を 行った結果, 磁界 Hy の強い箇所と弱い箇所, また, 中央 から $\mathrm{x}$ 軸方向へ磁界が緩やかに減衰し, $\mathrm{y}$ 軸方向へ急激に 減衰する磁界分布傾向の樣子等を含めて，両者は良好に一 致していることを確認した。

（4）実験を通して電波暗箱の設計に対する FDTD 法解 析の有効性を示すことができた。

以上，本論文全体を通して，電波暗箱の壁面を構成する 電波吸収体の性能と変動量分布の定量的な関係を示すこと ができ，また，実験を通して FDTD 解析の電波暗箱設計に 対する有効性を示すことができた。乥して，電波暗箱で近 傍電磁界の測定を行う場合の測定系の最適な配置や電波暗 箱の設計に対する有効な資料を提供することができた。今 後の課題として，2 層型や多層型電波吸収体を用い，電界 分布も含めた実験的検討があげられる。

謝 辞

本研究の一部は通信放送機構の委託により実施されたも のである。

(平成 14 年 9 月 3 日受付, 平成 15 年 4 月 10 日再受付)

$$
\text { 文献 }
$$

(1) Q. Han, K. Inagaki, K. Iigusa, and T. Ohira: "Study on Development of Compact Anechoic Chambers - Experimental Investigation of Distance between Antenna and Absorber-", Technical Report of IEICE, AP2000-205, pp.27-34 (2000-3) (in Japanese) 
韓 青・稲垣惠三・飯草恭一・大平 孝: 「小型電波暗箱の開発 検討光の1：アンテナと吸収体間の距離に関する実験」, 信学技報， AP2000-205, pp.27-34 (2000-3)

( 2 ) Q. Han, K. Inagaki, K. Iigusa, and T. Ohira: "Development of Compact Anechoic Chambers -Design,Prototyping, and Perfomance-", Technical Report of IEICE, AP2001-26, pp.39-46 (2001-5) (in Japanese)

韓 青・稲垣惠三・飯草恭一・大平 孝: ‘小型電波暗箱の開発検討 弚の 2 : 暗箱の設計と試作結果」, 信学技報, AP2001-26, pp.39-46 (2001-5)

( 3 ) Q. Han, K. Inagaki, K. Iigusa, and T. Ohira: "Development of Compact Anechoic Box -Antenna RF Current Measurement Based on a Reactive-Near-Field Probing Technique-" Technical Report of IEICE, AP2002-17, pp.37-42 (2002-5) (in Japanese)

韓 青・稲垣惠三・飯草恭一・大平 孝: 「小型電波暗箱の開発検 討兴の $3:$ 極近傍プロービングによるアンテナ RF 電流測定」, 信 学技報, AP2002-17, SAT2002-7, pp.37-42 (2002-5)

(4) Q. Han, K. Inagaki, K. Iigusa, R. Schlub, and T. Ohira: "Reactive-field anechoic box for ESPAR antenna measurement", IEICE Trans. Electron., Vol.E85-C, 7, pp.1451-1459 (2002-7)

（５）西村公佐・清水康敬·石野 健·三浦太郎:「電波暗室特性の数值シミュ レーションの検討」，信学技報，EMCJ88-4, pp.21-28 (1988-4)

(6) M. Inokuchi, E. Kimura, M. Tokuda, and K. Simada: "Improving Characteristic of Anechoic Chamber Using Ray Tracing Method", EMCJ98-91, pp.67-72 (1998-12) (in Japanese) 猪ノ口真三子·木村永寿·德田正満·島田 一夫:「レイトレーシング法 による電波無響室の特性改善」, EMCJ98-91, pp.67-72 (1998-12)

（7）清水康敬·杉浦 行·石野 健：最新 電磁波の吸収と遮蔽, pp.195202, 日経技術図書 (1999)

（8）橋本 修·阿部玩美: FDTD 時間領域差分法入門，森北出版 (1996)

（9）橋本 修: 電波吸収体入門，森北出版 (1996)

（10）安藤孝明・滝沢幸治・橋本 修・稲垣惠三・大平 孝 :「FDTD 法 を用いた小型電波暗箱内の電磁界解析」, 信学技報 , A ・ P 2001-37 (2001-6)

橋 本 利 紀 (非会員) 1979 年生。2002 年青山学院大学理工

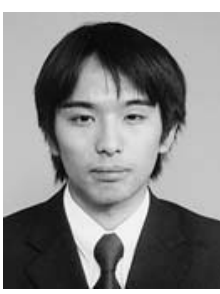
学部電気電子工学科卒業。現在, 同大大学院博士 前期課程在学中。
安藤 孝 明 (非会員) 1977 年生。2000 年青山学院大学理工

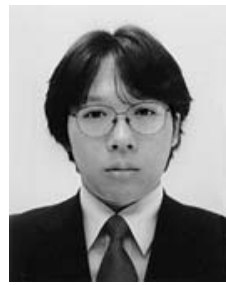
学部電気電子工学科卒業。2002 年同大学大学院 博士前期課程修了。同年日本電気 (株) 入社。

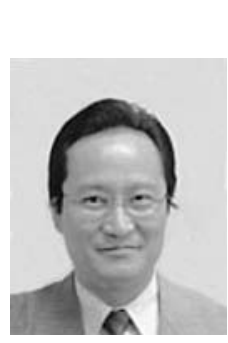

孝 (非会員) 1955 年生。1978 年大阪大学工学部通 信工学科卒業。1983 年同大学大学院博士課程了。 同年日本電信電話公社入社。横須賀電気通信研究 所にて準ミリ波高安定発振回路など超高周波機能 回路の MMIC 化の研究に従事。NTT ワイヤレス システム研究所にて技術試験衛星「きく6号」搭 載 GaAsMMIC 超小型軽量トランスポンダなら びに「ETS-VIII」搭載アクティブフェーズドア レーGaAsMMIC ビーム形成回路網の設計を担当。1999 年宇宙開発 事業団客員開発部員。2000 年大阪大学大学院電子工学特別講師。現 在, ATR 適応コミュニケーション研究所第 3 研究室長。アドホック 無線ならびにアダプティブアンテナのコンシューマ化の研究に従事。 工学博士。IEEE MTT-S Japan Chapter Vice Chair。共著書「モ ノリシックマイクロ波集積回路 (MMIC)」1997 年電子情報通信学会。 1986 年電子情報通信学会篠原賞。1998 年 Japan Microwave Prize 受賞。電子情報通信学会会員。IEEE Senior Member。

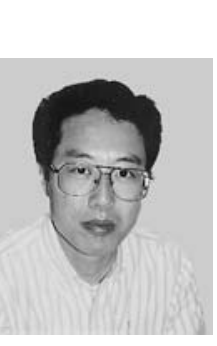

蓚 (正員) 1953 年生。1976 年電気通信大学電気通 信学部応用電子工学科卒業。1978 年同大学大学 院修士課程修了。同年 (株) 東芝入社。1981 年防 衛庁入庁。1986 年東京工業大学大学院博士課程修 了。1991 年青山学院大学助教授。1997 年青山学 院大学教授。工学博士。生体電磁工学, 環境電磁 工学，マイクロ波・ミリ波における計測に関する 研究に従事。著書「電波吸収体のはなし」(2001)， $\ulcorner$ 電気電子工学のための数値計算法入門」(1999) 「FDTD 時間領域差 分法入門」(1996)「「電波吸収体入門」(1995) 等。電子情報通信学会, エレクトロニクス実装学会, 日本航空宇宙学会, 映像情報メディア学 会, IEEE 各会員。 